Fisika FMIPA Universitas Negeri Medan.

\title{
PENGEMBANGAN PERANGKAT PEMBELAJARAN BERBASIS MASALAH UNTUK PENINGKATAN CAPAIAN KOMPETENSI FISIKA UMUM II MAHASISWA PRODI PENDIDIKAN FISIKA FMIPA UNIVERSITAS NEGERI MEDAN
}

\author{
Jurubahasa Sinuraya, Sehat Simatupang, dan Ida Wahyuni \\ Jurusan Fisika FMIPA Unimed \\ Jb_sinuraya@yahoo.com
}

\begin{abstract}
Abstrak. Tujuan utama penelitian ini adalah untuk menghasilkan lembar kegiatan mahasiswa berbasis masalah (LKMBM) Fisika Umum II. Penelitian ini termasuk jenis penelitian $\mathrm{R} \& \mathrm{D}$, namun untuk menghasilkan perangkat pembelajaran LKMBM digunakan model disain Dick dan Carey. Struktur isi LKMBM Fisika Umum II ini merupakan implementasi dari konsep pembelajaran berbasis masalah, dan konsep strategi pemecahan masalah. Pelaksanaan penelitian ini dibagi atas tiga tahapan yaitu tahap perencanaan, pengembangan, dan evaluasi formatif. Pelaksananaan evaluasi formatif dilaksanakan melalui tiga tahapan, yaitu: uji validasi oleh 3 orang reviewer, uji coba satusatu melibatkan 3 orang mahasiswa, uji coba kelompok kecil melibatkan 15 orang mahasiswa. Berdasarkan hasil analisis data dan pembahasan, hasil penelitian ini adalah: (1) seperangkat lembar kegiatan mahasiswa berbasis masalah (LKMBM) Fisika Umum II yang ditata dalam 10 komponen, yaitu: (a) judul kegiatan, (b) tujuan pembelajaran, (c) permasalahan, (d) hipotesis, (e) pengumpulan data, (f) pembahasan, (g) simpulan, (h) daftar pustaka, (i) lampiran, dan (j) tes kompetensi; 2) hasil uji coba LKMBM beserta perangkatperangkat pendukungnya dengan melibatkan para ahli dan mahasiswa sebagai pengguna LKMBM, secara keseluruhan sudah memberikan penilaian yang baik, layak digunakan dalam perbaikan pembelajaran fisika umum.
\end{abstract}

Kata kunci: perangkat pembelajaran, lembar kegiatan mahasiswa, berbasis masalah, dan kompetensi

\section{DEVELOPMENT OF PROBLEM BASED LEARNING DEVICES FOR INCREASING ACHIEVEMENT OF COMPETENCE GENERAL PHYSICS II IN PHYSICS EDUCATION STUDY PROGRAM, STATE UNIVERSITY OF MEDAN}

\author{
Jurubahasa Sinuraya, Sehat Simatupang, and Ida Wahyuni \\ Departement of Physics Sciences Faculty of Unimed \\ Jb_sinuraya@yahoo.com
}

\begin{abstract}
The main objective of this research is to construct problem based student activities sheet for Advance General Physics. Research and Development method is used in this research. However, Dick and Carey model is used for constructing learning devices. This research is implementation of research based learning and problem solve strategy concepts. There are three steps in this research; planning, building, and formative evaluating. In formative
\end{abstract}


evaluation is divided by three part; validation test by three reviewers, one-one test by three students, small group test by 15 students. Result of this research is problem based student activities sheet for advance general physics set in 10 components; they are (a) activity title, (b) learning goal, (c) problems, (d) hypothesis, (e) data collection, (f) discussion, (g) conclusion, (h) references, (i) attachment, and (j) competency test. In addition, the result of implementing student activities sheet and supporting learning device can give good assessment. This means that this problem based of student activity sheets can be used for improving advance general physics learning.

\section{Keywords: learning devices, student activity sheets, based problems, and competence}

\section{PENDAHULUAN}

Upaya perbaikan mutu lulusan Universitas Negeri Medan (Unimed) secara terusmenerus dilakukan. Upaya-upaya tersebut antara lain adalah menggunakan kurikulum berbasis kompetensi (KBK) sistem blok berbasis soft skill yang saat ini dinamakam pendidikan karakter.

Upaya perbaikan tersebut wajib dilaksanakan semua jurusan di Unimed termasuk Jurusan Fisika dalam menyelenggarakan kegiatan pembelajaran kepada mahasiswa. Dalam kenyataanya di lapangan, upaya-upaya tersebut belum berhasil, khususnya dalam mata kuliah MIPA Dasar. Salah indikator yang menggambarkan bahwa upaya-upaya tersebut belum optimal adalah hasil uji kompetensi Fisika Umum masih rendah. Rendahnya capaian kompetensi Fisika Umum oleh mahasiswa Jurusan Fisika FMIPA Unimed tergambar dari hasil tes kompetensi (NF3) yang terdapat pada DPNA Fisika Umum tahun ajaran: 2008/2009, 2009/2010, 2010/2011. 2011/2012, dan 2012/2013 secara rata-rata adalah $<70$ (belum kompeten).

Salah satu pendekatan pembelajaran yang berpusat pada mahasiswa (SCL) adalah pembelajaran berbasis masalah (Problem-Based Learning/PBL). Pembelajaran berbasis masalah merupakan salah satu peneekatan pengajaran di mana sintak awalnya menggunakan masalah sebagai langkah awal dalam mengumpulkan dan mengintegrasikan pengetahuan baru. Nurhadi (Handayani, 2009), dijelaskan bahwa $P B L$ adalah suatu model pembelajaran yang menggunakan masalah dunia nyata sebagai suatu konteks bagi mahasiswa untuk belajar tentang cara berpikir krtitis dan keterampilan pemecahan masalah, serta untuk memperoleh pengetahuan dan konsep esensial dari materi pelajaran, memperkaya dan mengembangkan ilmu pengetahuan, keterampilan dan sikapnya.

Esensial pembelajaran berbasis msalah (problem-based learning/PBL) berupa pemberian berbagai situasi masalah yang autentik dan bermakna kepada si-belajar (mahasiswa) yang dapat berfungsi sebagai landasan bagi si-belajar (mahasiswa) untuk melakukan investigasi dan penyelidikan (Arends, 2007). Sejalan dengan pandangan Aren, Handayani (2009) mendefinisikan bahwa $P B L$ adalah suatu pendekatan pengajaran yang menggunakan masalah dunia nyata sebagai suatu konteks bagi mahasiswa untuk belajar tentang cara berpikir kritis dan keterampilan pemecahan masalah, serta untuk memperoleh pengetahuan dan konsep yang esensial dari materi pelajaran.

Menurtu Barrows; Gallagher, Stepisn, Sher, dan Workman (Sungur, dkk., 2006) dijelaskan bahwa dalam lingkungan PBL, mahasiswa bertindak sebagai profesional dan dihadapkan dengan masalah yang mengharuskan mereka untuk (a) mendefinisikan masalah terstruktur seacara jelas, (b) mengembangkan hipotesis, (c) meng-akses, menganalisis, dan meng-gunakan data dari berbagai sumber, (d) merevisi hipotesis awal sebagai data yang dikumpulkan; dan (e) mengembangkan dan 
Sinuraya, J., Simatupang, S., dan Wahyuni, I.: Pengembangan Perangkat Pembelajaran Berbasis Masalah Untuk Peningkatan Capaian Kompetensi Fisika Umum II Mahasiswa Prodi Pendidikan Fisika FMIPA Universitas Negeri Medan.

membenarkan solusi sesuai dengan bukti-bukti dan penalaran. Selain itu, PBL dapat meningkatkan keterampilan berfikir kritis, komunikasi saling menghargai, kerja tim, meningkatkan keterampilan interpersonal, dan meningkatkan minat belajar (Gordon, dkk., 2001).

Menurut Slavin (Ismaimuza, 2010) dijelaskan bahwa karakteristik yang terkandung dalam PBL adalah pengajuan pertanyaan terhadap masalah, fokus pada keterkaitan antar disiplin, penyelidikan authentik, kerja sama, dan menghasilkan produk untuk dipamerkan.

Jacobsen, dkk. (2009), menyebut istilah pembelajaran berbasis masalah dengan pengajaran pemecahan masalah, yaitu pemecahan masalah yang diawali dengan satu maslah di mana mahasiswa bertanggungjawab untuk memecahkannya dengan bantuan dari dosen. Lebih lanjut dijelaskan, langkah-langkah pembelajaran pemecahan masalah ada lima, yaitu: (1) mengidentifikasi maslah, (2) menegaskan masalah, (3) memilih sebuah strategi, (4) melaksanakan strategi tersebut, dan (5) mengevaluasi hasil-hasil.

Deskripsi yang sedikit berbeda, langkahlangkah pembelajaran berbasis masalah menurut Darmawan (2010) juga terdiridari lima langkah yaitu: (1) orientasi mahasiswa pada masalah, (2) mengorganisasikan mahasiswa untuk belajar, (3) membimbing penyelidikan individualisasi ataupun kelompok, (4) mengembangkan dan menyajikan hasil karya, dan (5) menganalisis dan mengevaluasi proses pemecahan masalah.

Salah satu cara untuk meng-aplikasikan pembelajaran aktif kooperatif adalah dengan memberi pertanyaan (Paulson \& Faust, 1998; McConnell, 2001). Pertanyaan dirancang dalam bentuk lembaran kerja mahasiswa berbasis masalah (LKMBM). Pemberian pertanyaan dibuat secara terstruktur mengikuti sintaks $P B L$. Pembelajaran aktif adalah pembelajaran yang menekankan keterlibatan aktif mahasiswa. Dosen berperan sebagai fasilitator yang menciptakan kondisi lingkungan yang membuat mahasiswa mengkonstruksi sendiri materi kuliah.

$P B L$ dipilih karena dalam pelaksanaannya dapat mengakomodasi mahasiswa untuk
Jurnal Pendidikan Fisika

p-ISSN 2252-732X

e-ISSN 2301-7651

memberdayakan keterampilan berpikir kreatifnya. Mahasiswa didorong untuk mengutarakan gagasan yang bervariasi dan memberikan kesempatan mahasiswa untuk menginterpretasikan suatu fenomena atau demonstrasi, aktivitas ini dapat mengakomodasi aspek kete-rampilan berpikir kreatif yaitu fluency dan flexibility. Tahap selanjutnya mahasiswa mengumpulkan informasi yang sesuai untuk mendapatkan penjelasan dan pemecahan masalah, mahasiswa dapat menambahkan ide-ide orisinilnya dalam pemecahan masalah. Kegiatan ini akan membantu mahasiswa mengembangkan aspek originality. Mahasiswa kemudian merencanakan dan menyiapkan laporan dan menyajikannya kepada teman-teman yang lain. Pada kegiatan ini diharapkan mahasiswa lain dapat menambahkan gagasannya untuk memperkaya gagasan yang sudah dipresentasikan, sehingga mengembangkan aspek kemampuan memperinci atau elaboration. Kemam-puan untuk menilai akan muncul pada proses $P H B L$ pada tahap analisis dan evaluasi pemecahan masalah, dengan dibantu oleh guru, mahasiswa memberikan pertimbangan terhadap penyelesaian suatu masalah yang telah dikemukakan atas dasar sudut pandangnya sendiri. Selain itu, $P B L$ melibatkan mahasiswa secara aktif dalam menemukan masalah dan mengutarakan alternatif-alternatif pemecahannya. Sehingga mahasiswa tidak merasa jenuh karena dilibatkan secara aktif dalam pembelajaran.

Penerapan $P B L$ dan model pembelajaran lainya yang menjadikan mahasiswa sebagai pusat belajar sering menjadi gagal karena perangkat pembelajaran tidak tersedia. Salah satu perangkat pembelajaran untuk dapat menjadikan penerapan $P B L$ berhasil di lapangan melengkapi perangkat pembelajaran salah satu diatantaranya adalah lembar kerja mahasiswa (LKM) yang formatnya sesuai dengan model atau pendekatan pembelajaran yang diterapkan. Dalam penelitian ini menggunakan konsep PBL dan konsep pemecahan masalah, maka LKM yang dikembangkan menjadi lembar kegiatan mahasiswa berbasis masalah (LKMBM). 
Sinuraya, J., Simatupang, S., dan Wahyuni, I.: Pengembangan Perangkat Pembelajaran Berbasis Masalah Untuk Peningkatan Capaian Kompetensi Fisika Umum II Mahasiswa Prodi Pendidikan Fisika FMIPA Universitas Negeri Medan.

Pengembangan LKMBM berkaitan dengan karateristik yang mengguna-kannya. Pengguna di perguruan tinggi (mahasiswa) misalnya, penguasaan keterampilan-keterampilan umum semakin dituntut disamping keterampilan khusus dalam dalam setiap bidang ilmu (Luca \& Oliver, 2002). Hal ini menggambarkan bahwa mahasiswa sebagai calon guru fisika nantinya perlu dibekali penguasaan konsep fisika umum yang berorientasi pada masalah.

Salah satu cara untuk meng-aplikasikan pembelajaran aktif-kooperatif adalah dengan memberi pertanyaan (Paulson \& Faust, 1998; McConnell, 2001). Pertanyaan dirancang dalam bentuk Lembaran Kerja Mahasiswa (LKM). Pemberian pertanyaan dibuat secara terstruktur sesuai dengan saintak PBL, sehingga menuntut mahasiswa aktif dalam kegiatan pembelajaran. Pembelajaran aktif adalah pembelajaran yang menekankan keterlibatan aktif mahasiswa. Dosen berperan sebagai fasilitator yang menciptakan kondisi lingkungan yang membuat mahasiswa mengkonstruksi sendiri materi kuliah.

Temuan penelitian yang berkaitan dengan perangkat pembelajaran, temuan penelitian Sinuraya (2004) menyatakan bahwa salah satu faktor yang menyebabkan rendahnya hasil belajar Fisika Umum di FMIPA Unimed adalah penerepan model pembelajaran berbasis aktivitas serta perangkat pembelajaran yang mendukungnya masih sangat kurang. Perangkat pembelajaran yang digunakan sama oleh Tim Dosen Fisika Umum adalah GBPP Fisika Umum, kontrak perkuliahan, dan Diktat Fisika Umum, dan tes kompetensi (formatif ketiga) yang dilaksanakan oleh fakultas. Perangkat pembelajaran lainnya seperti model atau metode pembelajaran, media, lembar kerja mahasiswa, tugas-tugas, soal tes kompetensi, rubrik penilaian tidak sama, yang idelanya sama karena mata kuliah yang diajarkan adalah mata kuliah bersama (MIPA Dasar).

Salah satu cara untuk meningkatkan capaian kompetensi fisika umum bagi mahasiwa jurusan Fisika FMIPA Unimed adalah mengembangkan prangkat pembelajaran berbasis masalah yang sesuai dengan tuntutan kurikulum
Jurnal Pendidikan Fisika

p-ISSN 2252-732X

e-ISSN 2301-7651

yang digunakan oleh Tim Dosen Fisika Umum dapat digunakan oleh semua Tim Dosen Fisika Umum FMIPA Unimed. Perangkat pembelajaran berbasis masalah dapat meningkatkan kemampuan berpikir kritis, kreativitas mahasiswa (Gordon, dkk., 2001). Terjadinya peningkatan berpikir kritis dan kreativitas mahasiswa berpengaruh pada peningkatan hasil belajar mahasiswa.

\section{METODE PENELITIAN}

Jenis penelitian ini adalah adalah Research and Development (penelitian dan pengembangan). Produk yang dihasilkan pada kegiatan pengembangan perangkat pembelajaran ini dibatasi pada pengembangan lembar kegiatan berbasis maslah (LKMBM) Fisika Umum II. Langkahlangkah pengembangannya mengggunakan model desain Dick dan Carey (2009) yang terdiri dari 10 langkah, yaitu: 1) mengidentifikasi tujuan instruksional, 2) melakukan analisis instruksional, 3) menganalisis karakteristik peserta didik dan konteks, 4) merumuskan tujuan instruksional khusus, 5) mengembangkan instrumen penilaian, 6) mengembangkan strategi instruksional, 7) mengembangkan dan memilih bahan instruksional yang sesuai, 8) merancang dan melakukan evaluasi formatif, 9) melakukan revisi pembelajaran, dan 10) merancang dan melakukan evaluasi sumatif. Dari ke 10 tahapan pengembangan ini, tahapan kegiatan ke 10 tidak dilakukan.

Tes formatif bertujuan untuk mendapatkan kelemahan-kelemahan LKMBM yang digunakan untuk merevisi LKMBM sehingga produk yang dihasilkan menjadi lebih baik dari sebelumnya. Pelaksananaan tes formatif ini ini dilaksanakan melalui tiga tahapan, yaitu: (1) review 3 orang ahli yaitu: ahli materi, ahli strategi, dan ahli media; (2) uji coba satu-satu melibatkan 3 orang mahasiswa yang terbagi dalam tiga tingkatan kemampuan yaitu: kemampuan di atas rata-rata atau sangat baik, baik, dan cukup; (3) uji coba kelompok kecil melibatkan 15 orang mahasiswa yang dikelompokkan dalam 3 kelompok, 5 orang berkemampuan di atas rata-rata atau sangat baik, baik, dan berkemampua cukup. 
Fisika FMIPA Universitas Negeri Medan.

Perlu dijelaskan bahwa pelaksanaan tahapan tahap ke 4 yaitu uji kelompok besar/lapangan disebabkan keterbatasa waktu penyerahan laporan kegiatan pemberi dana hibah penelitain dengan pihak peneliti.

\section{HASIL PENELITIAN DAN PEMABAHASAN}

Adapun hasil-hasil pengembangan perangkat pembelajaran berbasis masalah dalam tulisan difokuskan pada pengembangan perangkat pembelajaran masalah fisika umum (LKBM) Fisika Umum II yang sudah dianalisis adalah sebagai berikut.

\section{1) Mengidentifikasi Tujuan Intruksional/ \\ Kompetensi}

Langkah pertama yang dilakukan dalam model-model desain sistem pembelajaran ini adalah menentukan kemampuan awal atau kompetensi yang perlu dimilki oleh peserta didik setelah menempuh program pembelajaran selama satu semester. Hal ini disebut dengan istilah tujuan pembelajaran (instructional goal). Identifikasi tujuan pembelajaran dikembangkan dari standar kompetensi dasar semester II yang tercantum dalam GBPP/Silabus Prodi Pendidikan Fisika FMIPA Unimed.

Tujuan instruksional yang berhasil diidentifikasi sebagai acuan dalam menentukan perangkat pembelajaran yang dibutuhkan untuk mencapai kompetensi Fisika Umum adalah dua rumusan tujuan instruksioanal/standar kompetensi, yaitu: (1) menerapkan metode ilmiah untuk menyelidiki fenomena alam, (2) menerapkan konsep, prinsip, dan hukum dalam cakupan materi fisika umum II. Dari kedua rumusan tujuan instruksional tersebut dikembangkan menjadi tujuan instruksional khusus/ kompetensi dasar. Jumlah rumusan instruksional khusus/kompetensi dasar yang telah dikemabangkan berjumlah delapan rumusan kompetensi dasar yang harus dikuasai oleh mahasiswaa dalam satu semester. Kopensi yang diharapkan dapat dicapai oleh mahasiswa setelah mengikuti pekuliahan Fisika Umum II selama satu semester dikelompokkan menjadi 4 tingkatan, yaitu kemampuan: (a) mengiden- tifikasi, (b) mendeskrip-sikan, (c) menerapkan, dan (d) meng-analisis.

\section{2) MelakukanAnalisis Instruksioanal}

Kegiatan analisis instruksional bertujuan untuk mengindentifikasi perilaku-perilaku khusus yang dapat menggambarkan perilaku umum secara lebih terperinci. Analisis instruksional merupakan keterampilan dan pengetahuan relevan yang diperlukan oleh peserta didik (mahasiswa) untuk mencapai kompetensi atau tujuan pembelajaran.

Deangan keterbatasan waktu, biaya, dan kemampuan maha hanya 4 kompetensi dasar yang dikembangkan indikatornya untuk keperluan pengembangan tes kompetensi, yaitu: (1) kompetensi dasar yang berkaitan dengan listrik statis, listrik dinamis, kemagnetan, dan listrik bolak balik (AC). Domain pembelajaran yang tekandung dalam rumusan indikator adalah aspek kognif.

\section{3) Menganalisis karakteristik peserta didik dan konteks}

Populasi sasaran yang akan dikenai kegiatan instruksional adalah mahasiswa semester II angkatan 2013/2014 Jurusan Pendidikan Fisika Universitas Negeri Medan. Populasi sasaran pada umumnya adalah lulusan SMA Jurusan IPA, yang diterina di Universitas Motivasi belajar mahasiswa mengikuti perkuliahan Fisika Umum cukup baik, diterima melaui SNM PTN, dasar pemilihan sesuai dengan minat dan bakatnya. Dengan demikian, perilaku dan karakteristik awal mahasiswa secara umum dapat diasumsikan homogen dalam mengikuti Fisika Umum II. Kalaupun terdapat perbedaan diharapkan dapat diatasi selama kegiatan instruksional berlangsung.

\section{4) Merumuskan tujuan instruksional khusus}

Rumusan kompetensi dasar yang dihasilkan dalam kegiatan ini terbatas pada aspek kognitif yang diadaptasi dari teori kognitif Bloom. Pemilihan aspek ini didasarkan pada hasil tes kompetensi beberapa tahun (3 tahun terakhir) masih angat rendah (data pada latar belakang). 
Sinuraya, J., Simatupang, S., dan Wahyuni, I.: Pengembangan Perangkat Pembelajaran Berbasis Masalah Untuk Peningkatan Capaian Kompetensi Fisika Umum II Mahasiswa Prodi Pendidikan Fisika FMIPA Universitas Negeri Medan.

\section{Mengembangkan Alat Ukur Instrumen}

Hal penting yang perlu mendapat perhatian dalam menentukan instrumen evaluasi yang akan digunakan adalah instrumen harus mampu mengukur performa mahasiswa dalam mencapai tujuan pembelajaran yang telah dirumuskan.

Penilaian belajar mahasiswa dilaksanakan meliputi: aspek substansi yang menggambarkan penguasaan kognitif, afektif, dan psikomotor dari setiap substansi yang dipelajari. Konsistensi dengan pendekatan pembelajaran berbasis kompetensi dalam pembelajaran, evaluasi belajar mahasiswa menggunakan pendekatan acuan patokan (PAP) yang dilaksanakan secara berkelanjutan baik menyangkut proses maupun hasil belajar mahasiswa.

\section{Mengembangkan Strategi Instruksional}

Kemampuan seorang dosen dalam memulai, menyajikan, dan menutup kegiatan pembelajaran merupakan modal utama dalam merencanakan kegiatan instruksional yang sistimatis. Apa yang diajarkan oleh dosen bukan saja harus relevan dengan tujuan instruksional mata kuliah tersebut, melainkan juga harus dikuasai dengan baik oleh mahasiswanya. Di samping itu, kegiatan instruksional yang diterapkannya harus menarik dan bervariasi.

Secara makro strategi instruksional merujuk pada aktivitas pembelajaran yang mencakup kegiatan awal, kegiatan inti, dan kegiatan penutup. Di dalamnya sudah termasuk media, materi, metode, dan penilaian. Namun secara mikro strategi pembelajaran merujuk pada metode atau pendekatan yang digunakan dalam mencapai tujuan yang telah ditetapkan (terlampir).

\section{Mengembangkan Bahan Instruksional}

Pengembangan bahan instruk-sional ada tiga macam, yaitu: (a) pengembangan bahan belajar mandiri, (b) pengembangan bahan pengajaran konvensional, dan (c) pengembangan bahan siswa PBS. Dasar pemlilihannya tergantung dari bentuk kegiatan instruksional yang akan dilakukan.

Dalam kegiatan pengembangan sistem sitruksional ini, bahan instruksional yang dikembangkan adalah pengembanhan bahan
PPS. Bahan PPS artinya pengajar sebagai penyaji bahan belajar yang dipilihnya, disingkat pengajar, bahan, siswa (PPS). Kegiatan instruksional PBS menggunakan bahan belajar yang telah ada di lapangan, dengan beberapa pertimbangan, yaitu: (a) Relatif efisien, (b) Kegiatan instruksional mudah disesuaikan dengan keadaan mahasiswa. Sistematika bahan instruksional terdiri dari: judul, pengantar, tujuan, bahan bacaan, latihan, lembar hasil latihan, alat, dan bahan, refleksi diri, glosaroum, dan daftar pustaka.

Sesuai dengan hasil penelitian awal yang terkait dengan kajian análisis kebutuhan perangkat fisika umum II, para responen (sampel) yaitu Tim Dosen Fisika Umum dan mahasiswa menggambarkan bahwa bahan ajar yang telah tersedia selama ini sudah cukup memadai untuk mendukung pelak-sanaan kegiatan instruksional. Sehu-bungan dengan hasil análisis kebutuhan tersebut, maka bahan ajar yang diha-silkan dalam penelitian ini termasuk bahan PPS

\section{5) Merancang dan melakukan evaluasi formatif}

\section{a. Review Ahli}

Pelakasanaan uji coba perangkat-perangkat pembelajaran yang telah dihasilkan melibatkan tiga orang review ahli yaitu: 1) ahli materi Prof. Dr. Nurdin Bukit, 2) ahli strategi Prof. Drs. Motlan, M,Sc., Ph.D, dan 3) ahli media Dr. Ridwan A. Sani. Ketiga reniew ahli tersebut merupakan dosen tetap di Jurusan Fisika FMIPA Universitas Negeri Medan (Unimed). Kepada mereka diberikan beberapa set perangkat pembelajaran Fisika Umum meliputi bahan ajar Fisika Umum, LKMBM Selanjutnya mereka diminta untuk memberi penilaian dan komentar tentang perangkat pembelajaran tersebut berdasarkan petunjukpetunjuk yang terdapat dalam kuesioner.

\section{1) Ahli Materi}

Untuk ahli materi jumlah komponen yang dinilai ada dua yaitu: 1) komponen kualitas materi dengan 6 pernyataan, dan 2) kesesuaian pilihan komponen pembelajaran untuk strategi pembelajaran berbasis masalah dengan 4 
Sinuraya, J., Simatupang, S., dan Wahyuni, I.: Pengembangan Perangkat Pembelajaran Berbasis Masalah Untuk Peningkatan Capaian Kompetensi Fisika Umum II Mahasiswa Prodi Pendidikan Fisika FMIPA Universitas Negeri Medan.

pernyataan, sehingga jumlah pernyataan yang harus dijawab oleh review ahli materi berjumlah 10 pernyataan. Nilai kuesioner yang diberikan oleh setiap Reviewer dideskripsikan:

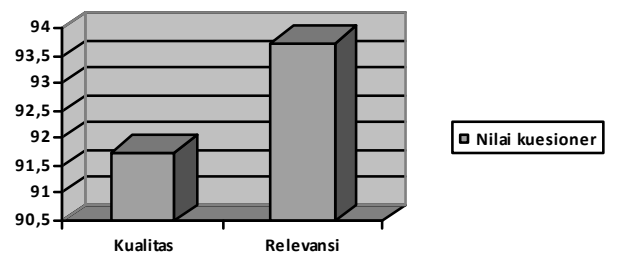

Gambar 1. Nilai Uji Coba Perangkat Pembelajaran Berbasis Masalah Oleh Reviewer Ahli Materi

Dari diagram 1 memberi penilaian oleh reviewer ahli materi nilai di atas 90 (sangat baik). Hal ini menggambarkan bahwa perangkat pembelajaran berbasis masalah Fisika Umum II yang telah dihasilkan melalui kegiatan penelitian pengembangan ini dari isi materi sudah layak digunakan sebagai perangkat pembelajaran dalam upaya menigkatkan kualitas dan hasil belajar fisika umum di Jurusan Fisika Unimed.

\section{2) Ahli Strategi}

Untuk ahli strategi jumlah kompenen yang dinilai ada 6 komponen yaitu: 1) komponen pembelajaran dengan 6 pernyataan, dan 2) kompoen tujuan/kompetensi pembelajaran dengan 3 pernyataan, 3) kom-penen materi 4) komponen strategi pembelajaran dengan 8 pernyataan, 5) komponen evaluasi pembelajaran dengan 2 pernyataan, dan 6) komponen relevansi pilihan komponen pembelajaran dengan pembelajaran berbasis masalah dengan 5 pernyataan, sehingga jumlah pernyataan yang harus diisi oleh ahli strategi adalah 24 pernyataan. Nilai kuesioner yang diberikan oleh setiap Reviewer dideskripsikan sebagai berikut:

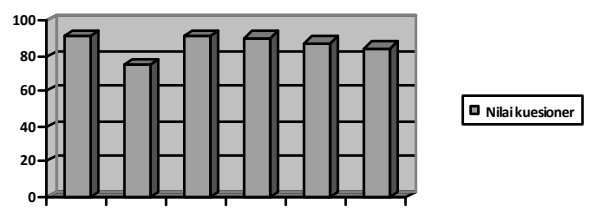

Gambar 2. Nilai Uji Coba Perangkat Pembelajaran Berbasis Masalah Oleh Reviewer Ahli Strategi.
Dari gambar 2 skor penilaian oleh reviewer ahli strategi pembelajara menggambarkan bahwa komponen 1), 3), dan 4) mencapai nilai 90 (sangat baik). Komponen 3), dan 6) dengan nilai antara 80 dan 90 (baik), dan komponen 2) dengan nilai antara 70 dan 80 (cukup). Nilai tersebut meng-gambarkan bahwa rata-rata dari keenam komponen mencapai nilai antara 80 dan 90 (baik). Dengan demkian perangkat pembelajaran berbasis masalah Fisika Umum II yang telah dihasilkan melalui kegiatan penelitian pengembangan ini dari isi komponen strategi pembelajaran yaitu berbasis masalah sudah layak digunakan dalam upaya menigkatkan kualitas dan hasil belajar fisika umum di Jurusan Fisika Unimed.

\section{3) Ahli Media Pembelajaran}

Dari aspek media, LMBM oleh ahli media pembelajaran, jumlah kompenen yang dinilai ada 6 komponen yaitu: 1) komponen penggunaan media dengan 4 pernyataan, dan 2) komponen tampilan media dengan 6 pernyataan, 3) kompenen pembelajaran dengan 8 pernyataan, dan 4) komponen relevansi pilihan komponen pembelajaran dengan pembelajaran berbasis masalah dengan 5 pernyataan, sehingga jumlah pernyataan yang harus diisi oleh ahli media adalah 23 pernyataan. Adapun nilai kuesioner yang diberikan oleh ahli media dideskripsikan sebagai berikut:

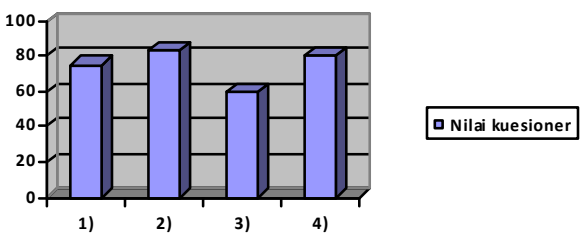

Gambar 3. Nilai Uji Coba Perangkat Pembelajaran Berbasis Masalah Oleh Reviewer Ahli Media Pembelajaran.

Dari gambar 3 skor penilaian oleh reviewer ahli media pembelajara menggambarkan bahwa komponen 2), dan 4) dengan nilai antara 80 dan 90 (baik), komponen 1) dengan nilai 70 dan 80 (cukup), dan komponen 3) dengan nilai 60 (kurang). 
Sinuraya, J., Simatupang, S., dan Wahyuni, I.: Pengembangan Perangkat Pembelajaran Berbasis Masalah Untuk Peningkatan Capaian Kompetensi Fisika Umum II Mahasiswa Prodi Pendidikan Fisika FMIPA Universitas Negeri Medan.

Saran-saran yang telah untuk menyempurnakan komponen 3 (komponen pembelajaran yang dimuat dalam lembar kegiatan berbasis masalahng) untuk dipertimbangkan dalam revisi berikutnya adalah: (a) Prosedur kerja dan tabel pengamatan tidak perlu dibuat, cukup dibuat petunjuk yang jelas bagi mahasiswa untuk mengumpulkan informasi untuk memecahkan masalah yang telah dituliskan dalam lebar kerja mahasiswa, dan (2) melengkapi tes kompetensi dalam setiap lembar kerja mahasiswa.

\section{b) Evaluasi Satu-satu}

Subjek yang dilibatkan dalam evaluasi satu-satu ini adalah mahasiswa berjumlah 3 orang yang setara dengan populasi sasaran, bertujuan untuk menilai dan mengomentari perangkat-perangkat pembelajaran fisika umum II yang telah dikembangkan. Adapun ketiga mahasiswa ini mempunyai kemampuan yang berbeda, yaitu satu orang rneniliki kemampuan di atas rata-rata (tinggi), satu orang memiliki kemampuan rata-rata (sedang), dan satu orang lagi memiliki kemampuan di bawah rata-rata (rendah). Penilaian kernampuan mahasiswa ini diperoleh dari dokumentasi DPNA Fisika Umum II mahasiswa di Jurusan Fisika FMIPA Universitas Negeri Medan. Dengan demikian ketiga mahasiswa diasumsikan dapat mewakili kemampuan seluruh mahasiswa. Masing-masing mahasiswa diberikan seperangkat lembar kegiatan mahasiwa berbasis masalah untuk diberi komentar.

Sebelum memberikan komentar, terlebih dahulu diberikan penjelasan maksud dan tujuan pengernbangan program ini, serta cara memberikan masukan. Setelah pemberian informasi (bimbingan) selesai dan sudah jelas bagi mahasiswa maksud dan tujuannya, selanjutnya secara individual ketiga mahasiswa diminta untuk menilai dan memberi komentar terhadap isi LKMBM. Untuk evaluasi satu-satu jumlah kompenen yang dinilai ada satu komponen dengan 7 pernyataan yang harus dijawab oleh ketiga mahasiswa.

Adapun respon yang diberikan oleh ketiga mahasiwa adalah seperti tergambar pada gambar 4 berikut.

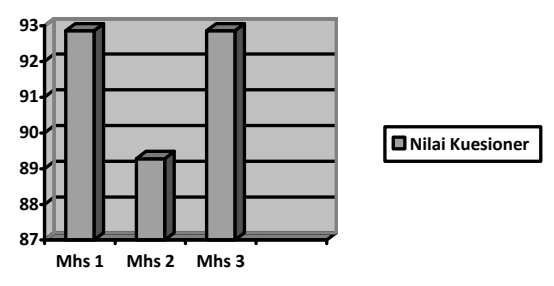

Gambar 4. Nilai Uji Coba Satu-satu Disain Model dan Perangkat Perangkat Pembelajaran Fisika Umum Oleh Mahasiswa

Dari gambar 4 skor penilaian oleh mahasiswa pertama dan kedua terletak pada rentang nilai 92-93 (sangat baik), dan penilaian mahasiswa ketiga terletak pada rentang nilai 89-90 (baik). Penilaian dari ketiga mahasiswa tersebut mengambarkan bahwa LKMBM ini layak digunakan sebagai perrangkat pembelajaran fisika umum II di jurusan Fisika FMIPA Unimed. Namun demikian, beberapa kelemahan yang mereka masih temukan antara lain: masih adanya beberapa gambar belum lengkap, dan beberapa kata yang salah ketik. Masukan tersebut dijadikan dalam LKMBM Fisika Umum II.

\section{c) Uji Coba Kelompok Kecil}

Dalam uji kelompok kecil ini, LKMBM beserta pendukung perangkat pembelajarannya lainnya seperti bahan ajar, dan media power point langsung digunakan oleh kelomppk mahasiswa sebagaimana dalam kelas yang sebenarnya (kelas peer teaching).

Jumlah mahasiswa yang dilibatkan dalam uji coba ini berjumlah 15 orang yang setara dengan populasi sasaran, bertujuan untuk menilai dan mengomentari perangkat-perangkat pembelajaran fisika umum II yang telah dikembangkan khususnya LKMBM. Adapun 15 orang mahasiswa ini mempunyai kemampuan yang berbeda, yaitu 5 orang rnemiliki kemampuan di atas rata-rata (tinggi), 5 orang memiliki kemampuan rata-rata (sedang), dan 5 orang lagi memiliki kemampuan di bawah rata-rata (rendah).

Setelah praktek penggunaan LKMBM dan perangkat pembelajaran lainnya diberikan dan telah selesai dipelajari oleh seluruh mahasiswa, selanjutnya diberikan tes kompetensi untuk 
Sinuraya, J., Simatupang, S., dan Wahyuni, I.: Pengembangan Perangkat Pembelajaran Berbasis Masalah Untuk Peningkatan Capaian Kompetensi Fisika Umum II Mahasiswa Prodi Pendidikan Fisika FMIPA Universitas Negeri Medan.

mengetahui tingkat kompetensi yang dicapainya. Pelaksanaan tes kompetensi dilakukan dua kali dengan waktu yang berbeda, dan materi yang diujikan juga berbeda. Tes kompetensi pertama dengan materi pokok listrik statis dan listrik dinamis, sedangkan tes kom-petensi kedua dengan materi pokok kemagnetan dan listrik AC. Masing-masing tes berjumlah 30 soal, bentuk tes pilihan ganda dengan 5 pilihan jawaban.

Deskripsi hasil uji coba kelompok kecil adalah seperti yang terdapat pada diagram 5 diagram 6 berikut ini.

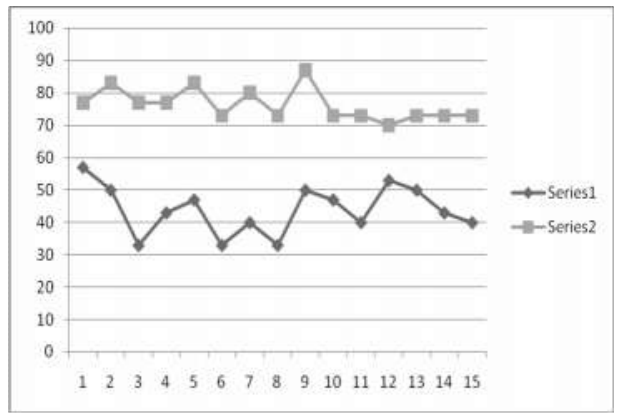

Gambar 5. Nilai Tes Kompetensi 15 orang Uji Coba Kelompok Kecil dalam Materi Pokok Listrk Statis dan Dinamis.

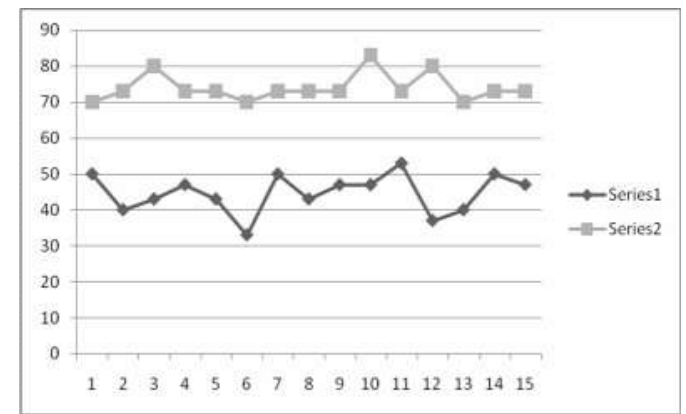

Gambar 6. Nilai Tes Kompetensi 15 orang Uji Coba Kelompok Kecil dalam Materi Pokok Kemagnetan dan Arus AC

Dari gambar 5 dan gambar 6 diperoleh bahwa hasil uji kelompok keci nilai pres dari 15 orang mahasiswa pada materi pokok listrik statis dan dinamis variasi nilai pretes: terendah 33 , tertinggi nilai 57, dan nilai postes -rata 44 . dan variasi nilai postes: terendah 70 , tertingg 83, dan rata-rata 76 ; sedangkan untuk materi pokok kemagnetan dan arus bolak balik variasi nilai pretes: terendah 33, tertinggi 53 , dan rata-rata 45 , variasi nilai postes: terendah 70 , tertinggi 83, dan rata-rata 74. Dari 5.5 dan 5.6 di atas terlihat dengan jelas bahwa capaian pos tes dari ke 15 mahasiswa uji coba mengalami peningkatan cukup baik dan semua nilai memenuhi standar minimal kelulusan yaitu nilai 70. Dengan demikian LKMBM dan perangkat pendukung lainnya yang digunakan kelompok kecil mahasiswa layak digunakan sebagai perangkat perangkat pembelajaran Fisika Umum II bagi mahasiwa dan dosen Fisika Umum.

\section{SIMPULAN}

Berdasarkan hasil penelituan pengembangan dan keterbatasan, maka beberapa kesimpulan dapat dideskripsikan sebagai berikut: 1) Penelitian ini menghasilkan lembar kerja mahasiswa berbasis masalah (LKMBM) dengan struktur isi terdiri dari 10 langkah, yaitu:(a) judul kegiatan, (b) tujuan pembelajaran, (c) permasalahan, (d) hipotesis, (e) Pengumpulan data, (f) pembahasan, (g) simpulan, (h) daftar pustaka, (i) lampiran, dan (j) soal-soal kompetensi; 2) hasil uji coba perangkat pembelajaran LKMBM yang dihasilkan beserta perangkatperangkat pendukung lainnya oleh para ahli dan mahasiswa (uji satu-satu) sebagai pengguna produk ini secara keseluruhan sudah memberikan penilaian kategori baik (layak digunakan dengan beberapa perbaikan), 3) hasil yang diperoleh dalam uji lapangan (uji kelompok kecil) menunjukkan adanya peningkatan hasil tes kompoetensi yang cukup baik dari hasil pre tes dan pos tes. Kenaikan ini memberi indikasi positip dengan adanya LKMBM Fisika Umum pembelajaran berbasis masalah yang bervariasi. Hasil uji coba kelompok kecil ini relevan dengan temuan penelitian Anwar, dkk.(2012) menyimpulkan bahwa pengembangan desain LKM berbasis pembelajaran aktif-koperatif dalam topik mekanisme reaksi yang dapat meningkatkan penguasaan konsep kinetika kimia dan keterampilan generik sains mahasiswa calon guru kimia. 
Sinuraya, J., Simatupang, S., dan Wahyuni, I.: Pengembangan Perangkat Pembelajaran Berbasis Masalah Untuk Peningkatan Capaian Kompetensi Fisika Umum II Mahasiswa Prodi Pendidikan Fisika FMIPA Universitas Negeri Medan.

\section{DAFTAR PUSTAKA}

Arends, R.I. 2007. Learning to Teach: Belajar untuk Mengajar Buku Dua Edisi Ketujuh. Yogyakarta: Pustaka Pelajar

Anwar, M., Liliasari., Setiabudi, A., dan Martoprawiro, M. 2012. Desain Lembaran Kerja Mahasiswa Berbasis Pembelajaran AktifKooperatif untuk meningkatkan Keterampilan Generik Sains Mahasiswa (Penerapan pada Topik Mekanisme Reaksi). Jurnal Chemica, Vo/. 13(1), 1-13.

Dick, W., Carey, L., dan Carey, J. 2009. The Systematic Design of Instructional. Illion: Scott, Foreresman \& Co.

Gordon, P.R., Roger, A.M., Comfort, M., Gavula,N., \& McGee,B.P. 2001. A taste of problem-based learning increases achievement of urban minority middleschool students. Educational Horizons, 79, 171-175.

Handayani, S. dan Sapir. 2009. Efektifitas Penerapan Model Pembelajaran Berbasis Masalah (Problem Based Learning) dan Pembelajaran Kooperatif (Cooperative Learning) Tipe Jigsaw untuk Meningkatkan Aktivitas Belajar, Hasil Belajar dan Respon Belajar Siswa pada Mata
Pelajaran Ekonomi di SMA Negeri 2 Malang. JPE, 2(1), 38-52

Ismaimuza, D. 2010. Kemampuan Berpikir Kritis dan Kreatif Matematis Siswa SMP melalui Pembelajaran Berbasis Masalah dengan Strategi Konflik Kognitif. Disertasi pada PPs UPI. Bandung: Tidak Diterbitkkan.

Jacobsen, David A., Eggen, Paul, dan Kauchak Donald. 2009. Methods for Teaching: Metode-metode Pengajaran Meningkatkan Belajar Siswa TK-SMA. Edisi ke8. Yogyakarta: Pustaka Kelajar.

Luca, J. \& Oliver, R. 2002. Developing an Instructional Design Strategy to Support Generic Skills Development [Online]. Tersedia: http://www.asclite.org.au/conferences/aucland02/Proceeding/papers/07 3.pdf. [13 Agustus 2014]

Paulson, D.R. \& Faust, J.L. 1998. Active Learning For The College Classroom, [Online]. Tersedia: http://www.calstatela. edu/dept/chem/chem2/Active/ index.htm [13 Agustus 2014]

Sungur, S. dan Tekkaya, C. 2006. Effects of Problem-Based Learning and Traditional Instruction on Self-Regulated Learning. The Journal of Educational Research, Vol. 99(5), 307-317. 